This article was downloaded by: [University of Sussex Library]

On: 04 February 2015, At: 07:13

Publisher: Routledge

Informa Ltd Registered in England and Wales Registered Number: 1072954

Registered office: Mortimer House, 37-41 Mortimer Street, London W1T

3J H, UK

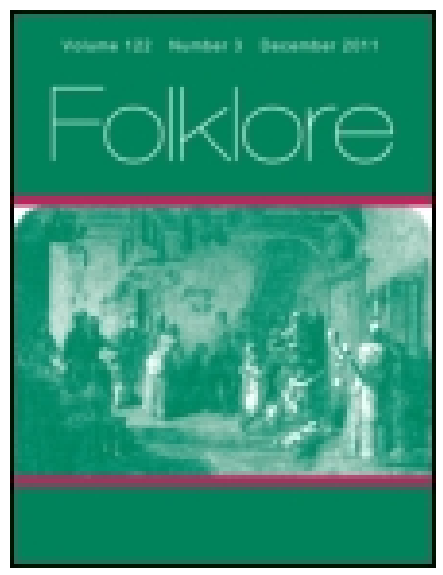

\title{
Folklore
}

Publication details, including instructions for authors and subscription information:

http:// www. tandfonline.com/loi/ rfol20

\section{Winning the Churn (Ulster)}

H. W. Lett ${ }^{a}$

${ }^{a}$ Aghaderg Glebe, Loughbrickland, County Down Published online: 06 Feb 2012.

To cite this article: $\mathrm{H}$. W. Lett (1905) Winning the Churn (Ulster), Folklore, 16:2, 185-186, DOI: 10.1080/0015587X. 1905. 9719449

To link to this article: http:// dx. doi. org/ 10.1080/0015587X.1905.9719449

\section{PLEASE SCROLL DOWN FOR ARTICLE}

Taylor \& Francis makes every effort to ensure the accuracy of all the information (the "Content") contained in the publications on our platform. However, Taylor \& Francis, our agents, and our licensors make no representations or warranties whatsoever as to the accuracy, completeness, or suitability for any purpose of the Content. Any opinions and views expressed in this publication are the opinions and views of the authors, and are not the views of or endorsed by Taylor \& Francis. The accuracy of the Content should not be relied upon and should be independently verified with primary sources of information. Taylor and Francis shall not be liable for any losses, actions, claims, proceedings, demands, costs, expenses, damages, and other liabilities whatsoever or howsoever caused arising directly or indirectly in connection with, in relation to or arising out of the use of the Content.

This article may be used for research, teaching, and private study purposes. Any substantial or systematic reproduction, redistribution, reselling, loan, sub-licensing, systematic supply, or distribution in any form to anyone is 
expressly forbidden. Terms $\&$ Conditions of access and use can be found at http://www.tandfonline.com/page/terms-and-conditions 


\section{Winning the Chorn (Ulster).}

(Ante, p. 130.)

Tre custom of "Winning the Churn" was prevalent all through the counties of Down and Antrim fifty years ago. It was carried out at the end of the harvest, or reaping the grain, on each farm or holding, were it small or large. Oats are the main crop of the district, but the custom was the same for other kinds of grain. When the reapers had nearly finished the last field a handful of the best-grown stalks was selected, carefully plaited as it stood, and fastened at the top just under the ears to keep the plait in place. Then when all the corn was cut from about this, which was known as "The Churm," and the sheaves about it had been removed to some distance, the reapers stood in a group about ten yards off it, and each whirled his sickle at the "Churn" till one lucky one succeeded in cutting it down, when he was cheered on his achievement. This person had then the right of presenting it to the master or mistress of the farm, who gave the reaper a shilling. In many cases, in the times I refer to, the reapers concluded with a supper and dance in the farm-house. The "Churn" after being cut was trimmed and adorned more or less with bits of coloured ribbon before being presented; and afterwards it was often improved in shape, and made neater, by the females of the household, and more bits of ornaments were sewn on it. It was then hung on the wall, or over a picture in the farmer's sittingroom or kitchen or hall, and carefully preserved. It was no uncommon sight to see six or a dozen or more Churns, the prizes of former yearn, decorating the walls of a County Down or Antrim farmer's residence.

Not long after the middle of the last century the scythe had begun to displace the sickle or "reaping-hook," and on many holdings the custom of the winning of the Churn ceased. And at the present day the introduction of reaping-machines and self-binding reapers has almost done away with the practice. However, it still keeps a hold on old farms where the occupier and his workpeople are sufficiently strong-minded not to be laughed out of observing an old custom, but though they plait their "Chwrn," they do not cast their sickles at it. 
The reaping the grain was always called "shearing the corn."

The "churn" exhibited is one of six, the trophies of the six years last past, hanging in the hall of my house. Six years ago the old "churns," ten or more in number, were burnt, as they had become shabby.

H. W. LEET.

Aghaderg Glebe, Loughbrickland, County Down.

Fin MacCouz's Pebelr.

(Ante, p.' 130.)

Brine Borv, Malachi of the golden collar, and the rest of the kings of Ireland were parvenus compared with Fin, and the Halls of Tara a modern villa residence compared with his abode under the vault of heaven. He and his wife dwelt in and about Carlingford, County Down, on the banks of Carlingford Lough, looking across to Rostrevor.

He was a determined giant, and ruled his wife with an iron hand, but the blood of giants did not run in her veins for nothing, so one day when Fin was more than usually unpleasant she told him that she would stand his nonsense no longer, calmly stepped across Carlingford Lough to where Rostrevor now stands, and ran up the green slope now called Rostrevor Mountain. Fin was not only surprised but incensed, so he picked up the nearest pebble and threw it at her. She was fleet of foot and it did not hit her; but there it remains to this day, a huge and slightly oscillating boulder known as Fin McCoul's Pebble, or otherwise as Cloughmore Stone. If any one can get on the top of it and wish, the wish is sure to be granted.

What became of the wife I never heard, but the giant can still be seen any day in the form of Carlingford Mountain, which from some points of view might bear a resemblance to the profile of a man with a receding forehead, an aquiline nose, and a rudimentary chin, surmounting an aldermanic figure.

L. J. Dennis. 